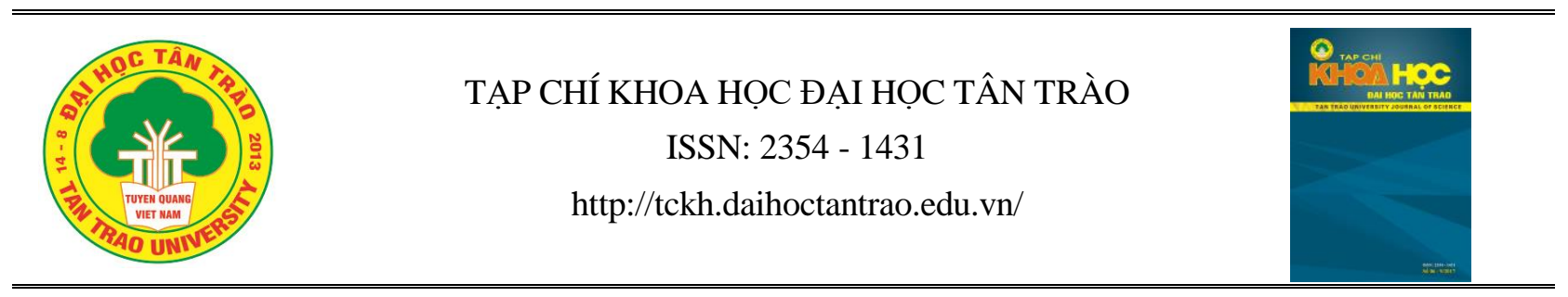

\title{
KHAI THÁC TIỀM NĂNG DU LỊCH SINH THÁI Ở HUYỆN LỤC NGẠN TỈNH BĂC GIANG
}

\author{
Nguyến Thị Hòa, Vi Thị Nhung ${ }^{a^{*}}$ \\ ${ }^{a}$ Truoòng Đại học Su phạm Thái Nguyên \\ *Email: hoant.his@tnue.edu.vn
}

Thông tin bài viết

Ngày nhận bài:29/4/2020

Ngày duyệt đăng:10/6/2020

Tù khóa:

Du lịch, Tiềm năng du lịch, Du lịch sinh thái, Lục Ngạn, Bắc Giang.

\section{Tóm tắt}

Ở Việt Nam, du lịch được xác định là một trong những ngành kinh tế mũi nhọn của đất nước. Du lịch không chỉ mang lại lợi ích kinh tế, đóng vai trò phát huy và bảo tồn những giá trị văn hóa truyền thống mà còn có ý nghĩa bảo vệ môi trường tự nhiên và xã hội với hình thức du lịch sinh thái. Mỗi địa phương ở nước ta đều có những tiềm năng phát triển du lịch nói chung và du lịch sinh thái nói riêng. Bài viết nhằm mục đích nghiên cứu về khai thác tiềm năng du lịch sinh thái ở huyện Lục Ngạn, tỉnh Bắc Giang. Chúng tôi sử dụng phương pháp lịch sử và phương pháp logic, các phương pháp nghiên cứu liên ngành (tổng hợp, thống kê, phân tích, so sánh...), đặc biệt là phương pháp điền dã dân tộc học để tiến hành tập hợp dữ liệu và thực hiện nghiên cứu. Bài viết làm rõ và đánh giá tiềm năng du lịch sinh thái, nghiên cứu thực trạng khai thác tiềm năng phát triển du lịch của địa phương; trên cơ sở đó xem xét và đề xuất định hướng, giải pháp nhằm khai thác hiệu quả tiềm năng phát triển du lịch sinh thái ở huyện Lục Ngạn, tỉnh Bắc Giang. Kết quả nghiên cứu góp phần khẳng định tiềm năng du lịch sinh thái của huyện Lục Ngạn và là cơ sở để địa phương xây dựng đề án tổng thể, định hướng, thực hiện các giải pháp để phát triển du lịch sinh thái và du lịch nói chung.

\section{1. Đặt vấn đề}

Theo Luật Du lịch năm 2017, Du lịch sinh thái là “loại hình du lịch dựa vào thiên nhiên, gắn với bản sắc văn hoá địa phuoong, có sụ tham gia của cộng đồng dân cu, kết hợp giáo dục về bảo vệ môi truò̀ng" [1]. Du lịch sinh thái là một loại hình du lịch hấp dẫn phát triển theo hướng bảo vệ môi trường sinh thái tự nhiên và phát huy các giá trị văn hóa truyền thống của địa phương, đồng thời nâng cao mức sống cho người dân khi tham gia vào hoạt động du lịch đóng góp tích cực vào sự phát triển kinh tế - xã hội của địa phương.

Yêu cầu cơ bản đầu tiên để phát triển du lịch sinh thái là cần sự tồn tại của các hệ sinh thái tự nhiên điển hình với tính đa dạng sinh thái cao. Yêu cầu thứ hai là người hướng dẫn ngoài kiến thức ngoại ngữ tốt còn phải là người am hiểu các đặc điểm sinh thái tự nhiên và văn hoá cộng đồng địa phương và phải có được người điều hành có nguyên tắc. Thứ ba là yêu cầu du lịch sinh thái cần được tổ chức với sự tuân thủ chặt chẽ các quy định về "sức chứa” (cả về vật lý, sinh học, tâm lý và xã hội) để hạn chế tới mức tối đa các tác động có thể của hoạt động du lịch sinh thái đến tự nhiên và môi trường. Yêu cầu thứ tư là thoả mãn nhu cầu nâng cao kiến thức và hiểu biết mới đối với tự nhiên, văn hoá bản địa của khách du lịch. Để đáp ứng được các yêu cầu trên, chúng ta cần thực hiện các nguyên tắc về môi trường; Các nguyên tắc về đạo đức, cách ứng xử và nguyên tắc thực hiện... [2].

Lục Ngạn là một huyện miền núi ở phía Đông Bắc tỉnh Bắc Giang với địa hình xen kẽ trung du và miền núi, khí hậu ôn hòa nên có nhiều cảnh quan thiên nhiên đẹp, hoang sơ, các vườn cây ăn quả trù phú - là vựa cây ăn quả lớn nhất miền Bắc. Bên cạnh đó, huyện Lục Ngạn còn là một vùng đất có bề dày truyền thống lịch sử với nhiều di tích lịch sử văn hóa có từ lâu đời $(2$ di tích lịch sử văn hóa cấp quốc gia, 39 di tích lịch sử văn 
hóa cấp tỉnh). Huyện còn là nơi tập trung sinh sống của các đồng bào dân tộc thiểu số Tày, Nùng, Cao Lan, Sán Chí,... với những bản sắc văn hóa đa dạng và độc đáo. Đây là những điều kiện thuận lợi để huyện khai thác phát triển mô hình du lịch sinh thái. Do đó, việc nghiên cứu khai thác tiềm năng du lịch sinh thái ở huyện Lục Ngạn, tỉnh Bắc Giang có ý nghĩa to lớn trong việc chỉ ra các tiềm năng phát triển du lịch sinh thái của huyện, trên cơ sở đó đánh giá thực trạng và đề xuất định hướng, giải pháp để khai thác hiệu quả tiềm năng du lịch một cách bền vững.

\section{Phương pháp luận và phương pháp nghiên cứu}

Tác giả dựa vào phương pháp luận của chủ nghĩa duy vật biện chứng và chủ nghĩa duy vật lịch sử để nhận diện, xem xét và đánh giá về tiềm năng và khai thác tiềm năng du lịch sinh thái ở huyện Lục Ngạn, tỉnh Bắc Giang.

Trong quá trình nghiên cứu, trình bày kết quả nghiên cứu, tác giả sử dụng phương pháp lịch sử và phương pháp logic là hai phương pháp chính. Phương pháp điền dã dân tộc học là phương pháp chủ đạo giúp khảo sát, đánh giá đối tượng nghiên cứu, thu thập tư liệu. Tác giả sử dụng các kỹ thuật như quan sát tham dự tại thực địa; phỏng vấn sâu, thảo luận nhóm; chụp ảnh và khảo tả. Chúng tôi tiến hành thực tế nghiên cứu, phỏng vấn tại địa phương từ tháng 10 năm 2019 đến tháng 5 năm 2020. Cụ thể, chúng tôi tiếp xúc phỏng vấn cán bộ quản lý từ cấp xã trở lên, trong đó có 2 cán bộ Phòng Văn hóa và Thông tin của huyện, 29 cán bộ văn hóa xã và thị trấn cùng 29 cán bộ là Chủ tịch, Phó chủ tịch Ủy ban nhân dân các xã, thị trấn về việc huyện/thị trấn/xã đã xây dựng đề án hay kế hoạch để phát triển du lịch sinh thái tại huyện chưa, các chương trình huyện đã thực hiện để thu hút khách du lịch và nhà đầu tư, huyện đã có đề xuất về việc khai thác, phát triển du lịch tại địa phương chưa; các hộ gia đình có miệt vườn, các hộ gia đình có đón khách du lịch và những người tham gia vào phát triển du lịch sinh thái như các loại hình/hoạt động du lịch mà du khách được trải nghiệm, quy mô các vườn cây là bao nhiêu ha, mức độ thường xuyên của du khách đến là bao nhiêu lượt/năm, những thuận lợi và khó khăn khi du khách đến tham quan gặp phải là gì. Sau đó, chúng tôi đến gặp các hộ gia đình có miệt vườn có khai thác dịch vụ du lịch và các hộ gia đình kinh doanh ở quanh các điểm du lịch, di tích trong địa bàn huyện, các chủ khách sạn/nhà nghỉ, chủ các nhà hàng/quán ăn... để phỏng vấn, điều tra về thực trạng khai thác các tiềm năng phục du lịch sinh thái của huyện, chính sách của các cấp chính quyền được triển khai tới các hộ gia đình như thế nào, những thuận lợi và khó khăn, nguyện vọng của người dân khi kinh doanh du lịch và phục vụ du lịch... Những thông tin, số liệu thu thập được chúng tôi xử lý, tổng hợp và dùng để phân tích trong báo cáo.

Ngoài các phương pháp trên, tác giả còn sử dụng phương pháp thống kê, phân tích, so sánh, tổng hợp và phương pháp phân tích SWOT để phân tích và đưa ra những đánh giá về điểm mạnh, điểm yếu, thời cơ, thách thức của việc khai thác các tiềm năng du lịch sinh thái và đưa ra được những giải pháp tối ưu để phát triển các nguồn lực đó.

Với các phương pháp nêu trên, tác giả nghiên cứu và làm rõ tiền năng; thực trạng, định hướng và giải pháp khai thác tiềm năng du lịch sinh thái của huyện Lục Ngạn. Bài viết đề cập tới 03 nội dung: 1 - Tiềm năng du lịch sinh thái của huyện Lục Ngạn, 2 - Thực trạng khai thác tiềm năng phát triển du lịch sinh thái ở huyện Lục Ngạn, 3 - Định hướng và giải pháp phát triển du lịch sinh thái huyện Lục Ngạn.

\section{Kết quả - bình luận}

\subsection{Tiềm năng du lịch sinh thái của huyện Lục} Ngạn

\subsubsection{Các tiềm năng và điều kiện phát triển du lịch}

a, Tài nguyên du lịch tụ nhiên. Lục Ngạn là một huyện miền núi ở phía Đông Bắc tỉnh Bắc Giang, cách trung tâm thành phố Bắc Giang 40km về phía Đông, cách thủ đô Hà Nội 90km về phía Bắc. Lục Ngạn là huyện có diện tích tự nhiên lớn nhất tỉnh Bắc Giang là $1.017,23 \mathrm{~km}^{2}$ với 29 đơn vị hành chính cấp xã trực thuộc. Đây là huyện có vị trí chiến lược quan trọng từ Thủ đô Hà Nội lên biên giới phía Đông Bắc. Lục Ngạn nằm trên trục đường quốc lộ 31 đi Sơn Động - Đình Lập (Lạng Sơn) và trục đường 279 đi Tân Sơn rồi sang Lạng Sơn. Ví trí địa lý như trên là điều kiện để Lục Ngạn giao lưu phát triển kinh tế - văn hóa - xã hội.

Lục Ngạn có địa hình là vùng núi cao và vùng đồi thấp, khí hậu của vùng nhiệt đới gió mùa và thổ nhưỡng có $59,93 \%$ đất Feralit. Các yếu tố trên thuận lợi cho việc hình thành và phát triển các đồi/vườn cây công nghiệp, cây ăn quả. Huyện Lục Ngạn đã hình thành tập đoàn cây ăn quả đa dạng bốn mùa, thơm ngon với hơn 26.000 ha. Trong đó, cây vải thiều là cây chủ lực với diện tích 15.290 ha (trong đó có 11.423 ha 
sản xuất theo tiêu chuẩn VietGap). Cây ăn quả có múi có 6.440 ha trong đó cam chiếm 3.945 ha, bưởi 2.165 ha. Các loại cây có múi đang có xu hướng phát triển mạnh [3].

Địa hình đa dạng, khí hậu thuận lợi kết hợp yếu tố thổ nhưỡng, thủy văn và sông ngòi cũng đã tạo cho Lục Ngạn cảnh quan tự nhiên hùng vĩ, thu hút với núi đồi, sông núi, hồ nước lớn..., hệ động thực vật phong phú.

b, Tài nguyên du lịch nhân văn. Về dân số và dân tộc, tổng dân số huyện Lục Ngạn là 223,8 nghìn người (năm 2018); tỉ lệ gia tăng dân số tự nhiên là $1,18 \%$. Số lao động của huyện Lục Ngạn khá dồi dào, năm 2018 có 158.450 nghìn người trong độ tuổi lao động. Dân cư trên địa bàn huyện Lục Ngạn gồm 8 dân tộc anh em cùng sinh sống (Kinh, Tày, Nùng, Cao Lan, Sán Chí, Sán Dìu, Hoa, Dao). Các dân tộc tại huyện Lục Ngạn sống hòa thuận, tôn trọng tập tục của nhau, hình thành nên sự giao thoa văn hóa cùng những nét đặc sắc riêng trong văn hóa các dân tộc [3].

Về di tích lịch sử văn hóa, Lục Ngạn là vùng đất có bề dày truyền thống lịch sử, đấu tranh chống giặc ngoại xâm với những chứng tích lịch sử như Động Giáp, Nội Bàng, Nam Điện,... Theo Phòng Văn hóa và Thông tin, trên địa bàn huyện có 41 di tích lịch sử văn hóa, trong đó có 2 di tích được công nhận cấp quốc gia (Đền Hả thuộc xã Hồng Giang, chùa Am Vãi thuộc xã Nam Dương) và 39 di tích được xếp hạng di tích cấp tỉnh [4].

Về lễ hội, hằng năm, huyện có nhiều lễ hội trải khắp các tháng. Tiêu biểu và đặc sắc như lễ hội Đền Hả, hội chùa Khánh Vân - đền Quan Quận, hội đền Tam Giang, hội đền Chể,... và hội chợ vùng cao với các điệu hát Soong Hao của dân tộc Nùng, điệu Soong Cô của dân tộc Sán Dìu, điệu Then tình tứ của người Tày hay điệu Sình ca của dân tộc Cao Lan,... Đặc biệt là những nét văn hóa này được hội tụ trong Ngày hội Văn hóa Thể thao các dân tộc huyện Lục Ngạn được tổ chức hằng năm vào ngày $18 / 2$ Âm lịch đã trở thành bản sắc văn hóa của mảnh đất và con người Lục Ngạn.

Lục Ngạn có các làng nghề thủ công truyền thống thu hút sự khám phá của du khách, sản phẩm thẩm mĩ và chất lượng, hấp dẫn như nghề làm mỳ Chũ ở thôn Thủ Dương, xã Nam Dương huyện Lục Ngạn; nghề dệt, thêu và nhuộm vải chàm của các dân tộc thiểu số sẽ là sản phẩm du lịch hấp dẫn trong tương lai.

Về ẩm thực, Lục Ngạn là nơi sinh sống nhiều dân tộc anh em, mỗi dân tộc lại có bản sắc văn hóa và phong cách ẩm thực riêng với các món ăn nổi tiếng như: Bánh Vắt Vai độc đáo của đồng bào người Sán Dìu; cơm lam, bánh trà lam, khâu nhục của người Tày - Nùng. Ngoài ra, huyện còn có một số đặc sản nổi tiếng như: Mật ong, vải thiều, nếp cái hoa vàng Phì Điền, rượu Kiên Thành, mỳ Chũ,... là các sản phẩm du lịch hấp dẫn các du khách.

c, Cơ sở hạ tầng và cơ sở vật chất kỹ thuật. Lục Ngạn có vị trí địa lí thuận lợi, nằm án ngữ trên 2 tuyến đường giao thông chính đó là: đường bộ theo tuyến đường Quốc lộ 31 Lạng Sơn - Sơn Động - Chũ - Thành phố Bắc Giang, tuyến theo Quốc lộ 279 Chũ - Tân Sơn - Chi Lăng - Đồng Mỏ (Lạng Sơn). Đường thủy theo sông Lục Nam xuôi về Vạn Kiếp - Phả Lại. Đây là vùng có vị trí trọng yếu trên đường từ thủ đô Hà Nội lên biên giới phía Đông Bắc. Đường tỉnh lộ 285, 289, 290 với tổng chiều dài $85 \mathrm{~km}$ đã được trải nhựa hết. Hiện nay xe ôtô đã đến được $100 \%$ các xã. Trên địa bàn huyện hiện có Bến xe khách với lưu lượng gần 100 lượt xe hoạt động/ngày. Ngoài ra, còn có hàng chục lượt xe buýt các tuyến Sơn Động - Bắc Giang, Sơn Động - Gia Lâm lưu thông qua địa bàn huyện. Cùng với đó có các tuyến xe khách từ Chũ đi các tỉnh thành khác như Thái Nguyên, Hải Phòng, Quảng Ninh, Hà Nội, các chuyến xe nước ngầm đi Hà Nội,... cũng hoạt động khá hiệu quả. Trên địa bàn huyện Lục Ngạn còn có khoảng 50 xe taxi của các hãng khác nhau. Hệ thống giao thông và cơ sở hạ tầng giao thông không chỉ dễ dàng cho việc đi lại, nâng cao đời sống vật chất của cư dân trong vùng mà còn là điều kiện giúp cho du lịch phát triển, thu hút khách tham quan tại các điểm du lịch.

Cùng với sự phát triển của thông tin liên lạc, các dịch vụ bưu chính viễn thông ở huyện Lục Ngạn cũng không ngừng phát triển cả về loại hình và phạm vi hoạt động, chất lượng dịch vụ được cải thiện, số lượng thuê bao di động cũng tăng nhanh với trên 10.000 thuê bao, các dịch vụ như chuyển phát nhanh, chuyển tiền nhanh, internet... đã đáp ứng được yêu cầu thông tin giữa huyện Lục Ngạn với các vùng trong cả nước và quốc tế, từ đó góp phần vào việc thúc đẩy nhanh tốc độ phát triển kinh tế xã hội của huyện Lục Ngạn.

Về cơ sở lưu trú, hầu hết hệ thống cơ sở lưu trú trên địa bàn huyện Lục Ngạn là nhà nghỉ/ Hiện nay, huyện có 1 khách sạn và 28 cơ sở đạt tiêu chuẩn kinh doanh nhà nghỉ, với 23 phòng khách sạn và 299 phòng nhà nghỉ đạt chuẩn trong đó những nhà nghỉ này tập trung chủ yếu ở Thị trấn Chũ - Trung tâm kinh tế, văn hóa, xã hội của huyện Lục Ngạn. Về cơ sở kinh doanh ăn uống thì toàn huyện có 3 nhà hàng lớn và các quán ăn ven đường nằm rải rác dọc tuyến Quốc lộ 31 và một số huyện lộ. Về cơ sở vật chất văn hóa, trên toàn huyện có 01 trung tâm văn hóa thể thao huyện; 10 sân tennis; 25 nhà thi đấu; 41 di tích lịch sử văn hóa; 01 thư viện... góp phần cho cộng đồng địa phương vui chơi giải trí, sinh hoạt cộng đồng. Hiện nay, nhiều nhà vườn được các hộ gia đình xây dựng tổ 
chức kinh doanh phục vụ khách dưới các hình thức cung cấp dịch vụ cho khách nhưng chủ yếu là ăn uống và tham quan trải nghiệm vườn đồi.

\subsection{2. Đánh giá tiềm năng và khả năng khai thác các tiềm năng}

Để đánh giá tiềm năng và khả năng khai thác các tiềm năng phát triển du lịch sinh thái ở huyện Lục Ngạn, chúng tôi sử dụng phương pháp SWOT. Thực hiện phân tích theo phương pháp SWOT, tôi đã xác định những điểm mạnh, điểm yếu, cơ hội và thách thức trong việc khai thác tiềm năng du lịch sinh thái huyện Lục Ngạn như sau:

Xét các yếu tố nội tại (nguyên nhân từ bên trong), điểm mạnh của tiềm năng du lịch sinh thái huyện Lục Ngạn là có vị trí địa lý thuận lợi, tài nguyên du lịch sinh thái phong phú, đa dạng; khí hậu nhiệt đới gió mùa, đất feralit đặc trưng thuận lợi trồng cây ăn quả nên hình thành nhiều vườn cây rộng lớn cho quả thơm ngon nổi tiếng; là nơi sinh sống của nhiều đồng bào dân tộc thiểu số nên các giá trị văn hóa của các dân tộc vẫn còn được lưu giữ; giao thông thuận tiện; điểm đến an ninh an toàn và thân thiện. Điểm yếu là công tác quy hoạch phát triển du lịch sinh thái chưa được thực hiện; nguồn nhân lực phục vụ du lịch còn thiếu và yếu, công tác đào tạo chưa được chú trọng; sản phẩm và dịch vụ du lịch chưa phong phú, chưa khai thác hết tiềm năng của vùng; các điểm vườn còn phát triển tự phát; công tác quảng bá còn hạn chế lẫn cả nội dung và phạm vi; hệ thống cơ sở vật chất kĩ thuật phục vụ du lịch còn hạn chế và chưa được chú trọng đầu tư; ý thức giữ gìn bản sắc văn hóa của người dân địa phương còn hạn chế.

Xét các yếu tố khách quan (nguyên nhân từ bên ngoài), cơ hội đối với du lịch sinh thái huyện Lục Ngạn là xu hướng phát triển chung du lịch sinh thái của thế giới và Việt Nam nhằm hướng tới mục tiêu phát triển bền vững; Nhà nước có chiến lược và chính sách ưu tiên đầu tư phát triển du lịch sinh thái; hoạt động xúc tiến quảng bá du lịch Lục ngạn và du lịch Việt Nam được đẩy mạnh giúp bạn bè quốc tế biết đến Việt Nam ngày càng nhiều hơn. Nhưng bên cạnh đó, du lịch sinh thái ở đây phải đối mặt với nhiều thách thức: Tình trạng ô nhiễm môi trường và biến đổi khí hậu ngày càng gia tăng; Việt Nam tham gia các Hiệp định, hiệp ước hợp tác ở quy mô quốc tế và khu vực; nhu cầu về chất lượng dịch vụ và sản phẩm đặc trưng địa phương ngày càng cao; sự phát triển của nền kinh tế trong bối cảnh hội nhập, toàn cầu hóa và mặt trái của công nghệ thông tin đem lại làm mờ nhạt giá trị văn hóa truyền thống bản địa; công tác quy hoạch, bảo vệ tôn tạo tài nguyên thiên nhiên và môi trường còn thấp.

3.2. Thực trạng khai thác tiềm năng phát triển du lịch sinh thái ở huyện Lục Ngạn
Huyện Lục Ngạn có tiềm năng và cơ hội để phát triển du lịch nói chung và du lịch sinh thái nói riêng. Nhằm khai thác các tiềm năng du lịch của địa phương, thực hiện Nghị quyết số 44-NQ/TU ngày 30/3/2015 của Ban Thường vụ Tỉnh ủy tỉnh Bắc Giang về việc phát triển du lịch tỉnh Bắc Giang, Ủy ban Nhân dân huyện Lục Ngạn đã xây dựng kế hoạch số 86 KH/UBND ngày 19/6/2016 để phát triển du lịch trên địa bàn huyện. Tuy nhiên, đến nay, chưa có đề án hay kế hoạch, quy hoạch tổng thể nào được thực hiện để phát triển du lịch địa phương. Theo lãnh đạo địa phương, đề án được xây dựng nhưng chưa được phê duyệt cấp kinh phí thực hiện. Bởi vậy, cho đến nay, du lịch và du lịch sinh thái ở Lục Ngạn hầu như vẫn dừng lại ở tiềm năng và khai thác nhỏ lẻ phục vụ cho nhân dân trong huyện và lân cận. Hoạt động kinh doanh du lịch chủ yếu xuất phát từ các gia đình tự phát thông qua hoạt động buôn bán hoa quả kết hợp tham quan vườn đồi; các hoạt động dã ngoại tự tổ chức của nhóm cá nhân... Năm 2019, du lịch huyện Lục Ngạn đã có những chuyển biến tích cực. Để đáp ứng nhu cầu tham quan của du khách và hưởng ứng Ngày hội trái cây Lục Ngạn, qua nhiều lần khảo sát và thuyết phục các chủ hộ vườn, Trung tâm Trải nghiệm Green Dream thuộc Công ty TNHH Giáo dục, Trải Nghiệm Green Dream có trụ sở ở thành phố Bắc Giang quyết định đầu tư phát triển du lịch ở một số xã trên địa bàn huyện Lục Ngạn, trong đó bước đầu lấy xã Thanh Hải làm trung tâm. Từ đầu tháng 11/2019 đến hết năm, Trung tâm Trải nghiệm Green Dream ở xã Thanh Hải đã đón tiếp hơn 1000 lượt khách trong và ngoài tỉnh. Chủ yếu khách đến từ Thủ đô Hà Nội và thành phố Bắc Giang do các Công ty Du lịch Việt Hưng Tourist, Du lịch Xuyên Việt, Du lịch Vietbiz Tour đưa đến tham quan trải nghiệm thu hái tại các vườn cây ăn quả và thăm quan các làng nghề trên địa bàn huyện [4].

Huyện Lục Ngạn đầu tư phát triển mô hình du lịch sinh thái cộng đồng gắn với trải nghiệm vườn cây ăn quả. Tuy nhiên, huyện còn nhiều hạn chế về hạ tầng giao thông và cơ sở vật chất phục vụ khách du lịch và trên địa bàn còn nhiều tuyến đường liên thôn chưa được bê tông hóa nên chưa hấp dẫn được nhiều du khách.

Theo ông Cao Văn Hoàn - Phó chủ tịch Ủy ban Nhân dân huyện Lục Ngạn: "Trong thời gian tới, huyện Lục Ngạn sẽ phát triển du lịch sinh thái nghỉ duỡng, huyện sẽ kết hớp với các doanh nghiệp phát triển các vuờn cây ăn quả đảm bảo đáp úng yêu cầu miệt vuờn đối với du khách". Trước hết, từ năm 2019 đến năm 2025, huyện sẽ huy động nguồn đầu tư hạ tầng ở vùng cây ăn quả tại hai xã đó là xã Tân Mộc và xã Quý Sơn. Cụ thể là huyện chọn thôn Hoa Quảng (xã Tân Mộc) và thôn Giành (xã Quý 
Sơn) để đầu tư xây dựng thí điểm mô hình này. Bằng các nguồn lực huyện Lục Ngạn sẽ đầu tư gần 15 tỷ đồng để cứng hóa đường giao thông liên thôn từ thôn Hoa Quảng đi thôn Đồng Quýt ở xã Tân Mộc; xây dựng nhà văn hóa, nhà vệ sinh công cộng. Trong hai năm (2019 - 2020), huyện bố trí cho thôn Giành và Hoa Quảng mỗi thôn hơn 1 tỷ đồng để xây dựng nhà trưng bày sản phẩm đặc trưng và nhà văn hóa. Ông Nguyễn Đức Toản thôn Giành (xã Quý Sơn) chia sẻ: "Truớc đây tuyến đuờng trong thôn chỉ rộng $2 m$, rất hẹp, mỗi khi đến mùa thu hoạch vải nguời dân đi lại rất khó khăn. Khi Ủy ban nhân dân huyện triển khai chuoong trình cứng hóa đường giao thông nông thôn, các hộ dân trong thôn vận động nhau bàn cách mở rộng đường. Đến nay toàn thôn đã hoàn thành cúng hóa khoảng $10 \mathrm{~km}$ đuoòng trục thôn, ngõ xóm với chiều rộng trung bình là $4 \mathrm{~m}$ ".

Ngoài các vườn cây ăn quả, các địa điểm sinh thái khác như hồ Khuôn Thần, hồ Cấm Sơn, đập Làng Thum,.. cũng có hoạt động du lịch. Danh thắng hồ Cấm Sơn là hồ thủy điện lớn thứ 4 miền Bắc nằm trên địa bàn 4 xã của huyện Lục Ngạn: Cấm Sơn, Sơn Hải, Tân Sơn, Hộ Đáp và 5 xã, thị trấn của huyện Hữu Lũng, huyện Chi Lăng của tỉnh Lạng Sơn. Trong hai năm 2018 - 2019, lượng du khách đến hồ Cấm Sơn tăng cao. Đặc biệt là trong các dịp lễ 30/4 - $1 / 5$ và mùa Hè, trung bình mỗi ngày có khoảng 2 nghìn lượt khách đến tham quan. Anh Trần Văn Nguyễn - chủ thuyền máy tại thôn Mới, xã Cấm Sơn cho biết: "Du khách đến hồ tham quan sẽ đi bằng thuyền máy của nguời dân ven hồ, mỗi thuyền có giá dao động khoảng $500-800$ nghìn đồng với sức chứa lên đến 30 nguời/thuyền. Các thuyền đều được trang bị áo phao và phao bơ cho du khách”. Đến hồ Cấm Sơn, du khách được tham quan các đảo nhỏ trên hồ, trải nghiệm các hoạt động như câu cá, bơi lội,... và thưởng thức các đặc sản của bà con dân tộc ở xung quanh hồ như vải thiều, na, nhãn, dứa, mật ong, gà đồi leo cây, cá nướng, cá bống nấu măng chua, xôi ngũ sắc,... Tuy nhiên, các dịch vụ phục vụ du lịch và cơ sở hạ tầng chưa phát triển nên du khách đến đây tham quan cần phải tự chuẩn bị hành trang và thực phẩm mang theo và không lưu trú được gần hồ, ngắm cảnh đêm. Trong Hội nghị xúc tiến đầu tư phát triển du lịch năm 2018 của tỉnh Bắc Giang, dự án đầu tư của Tập đoàn FLC đã được Ủy ban Nhân dân tỉnh Bắc Giang trao chứng nhân với kinh phí đầu tư gần 14 nghìn tỷ đồng vào khu vực hồ Khuôn Thần huyện Lục Ngạn nhưng đến nay dự án này vẫn chưa được tiến hành đúng tiến độ.

Tóm lại, dù đã có những chuyển biến tích cực nhưng huyện Lục Ngạn vẫn chưa có đề án phê duyệt cụ thể nào về quy hoạch và xây dựng đầu tư các điểm du lịch sinh thái thành một quần thể du lịch hấp dẫn mang đặc trưng vùng cây ăn quả nhiệt đới, chưa có sự phân vùng cho du lịch sinh thái và chưa xây dựng bản đồ chỉ dẫn tại các điểm khai thác hoạt động du lịch sinh thái. Cơ sở hạ tầng tại các điểm du lịch chưa được đầu tư xây dựng, giao thông kết nối các tour, tuyến chưa đồng bộ; chưa có các khu vui chơi hoạt động giải trí, khu trung tâm thương mại mua sắm. Hơn nữa việc đầu tư phát triển du lịch chỉ dựa trên cái mình có sã̃n và làm theo cách dễ làm nhất, chưa có sự chú trọng đến nhu cầu và mong muốn ngày càng cao của du khách. Do đó, các hoạt động du lịch sinh thái đang diễn ra trên địa bàn huyện Lục Ngạn còn mang tính tự phát trong nhân dân và xuất phát từ nhu cầu tìm kiếm các loại hình du lịch tự nhiên của du khách, hoạt động du lịch của huyện Lục Ngạn còn nhỏ lẻ, manh mún, các dịch vụ phục vụ du lịch chưa phong phú và đa dạng. Vì vậy, để khai thác tiềm năng để phát triển du lịch sinh thái huyện Lục Ngạn cần đưa ra những định hướng và biện pháp tối ưu để khác phục những hạn chế trong thời gian tới.

\section{3. Định hướng và giải pháp phát triển du lịch sinh thái huyện Lục Ngạn}

Thực hiện Quyết định 939/QĐ-UBND năm 2017 về điều chỉnh Quy hoạch phát triển Văn hóa - Thể thao và Du lịch tỉnh Bắc Giang đến năm 2020, tầm nhìn đến 2030, Đảng bộ và nhân dân huyện Lục Ngạn đang hướng tới mục tiêu phát triển du lịch trở thành ngành kinh tế mũi nhọn trong đó tập trung vào loại hình du lịch văn hóa tâm linh, sinh thái nghỉ dưỡng. Để phát triển du lịch sinh thái, đòi hỏi huyện Lục Ngạn cần có những hướng đi mới và có thể đề ra những định hướng cơ bản sau:

Một là, định hướng phát triển các hình thức du lịch sinh thái kết hợp với các loại hình du lịch đa dạng. Bao gồm: Du lịch sinh thái: tham quan vườn cây ăn quả; du lịch sinh thái nghỉ dưỡng gắn với du lịch tâm linh: hồ Khuôn Thần, hồ Cấm Sơn, chùa Am Vãi...; du lịch văn hóa lịch sử, sinh thái nhân văn: Đền Hả, chùa Am Vãi, hồ Khuôn Thần,...; du lịch dã ngoại (bơi thuyền, leo núi, câu cá) hồ Cấm Sơn, hồ Khuôn Thần,...

Hai là, định hướng phát triển du lịch theo lãnh thổ. Để có thể thâm nhập vào thị trường khách nội địa và khách quốc tế thì Lục Ngạn cần tập trung phát triển du lịch mang đặc trưng riêng của vùng là du lịch miền sơn cước với các loại hình vui chơi, giải trí, văn hóa, nghệ thuật truyền thống của huyện, vừa phục vụ du khách, vừa giữ gìn và phát huy bản sắc văn hóa của dân tộc như hát dân ca của các dân tộc Nùng, Tày, Cao Lan, Sán Chí; hoặc tham quan các vườn cây ăn quả. Một trong những điểm cần lưu ý trong chiến lược phát triển du lịch sinh thái huyện Lục Ngạn là việc đa dạng hóa các sản phẩm du lịch gắn với 
từng vùng lãnh thổ của huyện, đáp ứng nhu cầu của các đối tượng khách du lịch. Bên cạnh đó, huyện cần hợp tác với các huyện như Lục Nam, Sơn Động,... để xây dựng các tuyến du lịch (tour), liên kết các điểm du lịch theo từng nội dung để thu hút khách du lịch.

Trên cơ sở định hướng như trên, chúng tôi đề xuất một số giải pháp nhằm khai thác hiệu quả tiềm năng du lịch sinh thái ở huyện Lục Ngạn như sau:

Thư nhất, cần xây dụng bản đồ quy hoạch phát triển du lịch sinh thái. Để khai thác các tiềm năng của huyện Lục Ngạn phát triển du lịch sinh thái, Ủy ban Nhân dân huyện cần xây dựng bản đồ quy hoạch các điểm du lịch sinh thái một cách chi tiết, cụ thể và mang tính khoa học cao phù hợp với từng địa điểm và giai đoạn quy hoạch du lịch. Khi quy hoạch phát triển du lịch sinh thái huyện Lục Ngạn cần đảm bảo môi trường sinh thái luôn được bảo vệ, không làm mất cảnh quan của khu du lịch; đảm bảo giữ vững những nguyên tắc phát triển bền vững của du lịch sinh thái.

Hai là, giải pháp về co chế, chính sách. Để đảm bảo giữ gìn được tài nguyên môi trường sinh thái huyện Lục Ngạn cho phát triển bền vững cần phải ban hành một số cơ chế, chính sách về bảo tồn thiên nhiên trên cơ sở phát triển bền vững. Việc lựa chọn và xây dựng các địa điểm du lịch, khu vui chơi giải trí cần phải tuân theo các nguyên tắc của việc phát triển du lịch sinh thái. Các chính sách tạo điều kiện thuận lợi để khuyến khích du lịch sinh thái phát huy bản chất, vai trò hỗ trợ, bảo tồn và phát triển cộng đồng ở các điểm du lịch sinh thái. Ban hành các cơ chế chính sách về đầu tư, sử dụng vốn ngân sách, thị trường để tạo điều kiện hỗ trợ cho sự phát triển du lịch sinh thái. Huyện cần xây dựng cơ chế hợp tác giữa khu vực công và khu vực tư nhân, phân định rõ vai trò, trách nhiệm, lợi ích của các bên. Cơ quan quản lý nhà nước tạo môi trường thông thoáng, hỗ trợ, khuyến khích các doanh nghiệp chủ động phát huy vai trò góp phần tạo động lực thúc đẩy phát triển du lịch của địa phương.

Ba là, đầu tu, nâng cấp hệ thống co sở vật chất - kĩ thuật, hạ tầng phục vu du lịch. Để đầu tư xây dựng và nâng cấp hoàn thiện cơ sở vật chất - kĩ thuật, hạ tầng du lịch, chính quyền và nhân dân địa phương cần: Nâng cấp hệ thống giao thông liên xã, liên thôn để tạo điều kiện thuận lợi kết nối tuyến du lịch nội huyện, rút ngắn thời gian di chuyển giữa các địa điểm hâp dẫn du lịch trên địa bàn huyện Lục Ngạn; cần đầu tư xây dựng các trung tâm tư vấn, cung cấp thông tin, hướng dẫn du lịch địa phương và lắp đặt các bản chỉ dẫn du lịch; kêu gọi và khuyến khích các doanh nghiệp đầu tư cơ sở lưu trú có chất lượng cao với nhiều tiện ích, dịch vụ bổ sung đa dạng như bến thuyền, bãi đậu xe, các chòi tre nứa, gõ, mái bằng lá cọ, để phục vụ cho việc quan sát khám phá thiên nhiên và hoạt động câu cá của du khách; các cơ sở kinh doanh ăn uống có sức chứa lớn cho khách đoàn, có bãi đậu xe ô tô, cải thiện chất lượng món ăn và đa dạng hóa các loại hình dịch vụ để đáp ứng nhu cầu của du khác; cần xây dựng và phát triển hệ thống cửa hàng đặc sản địa phương nhằm tận dụng nguồn sản phẩm nông nghiệp cũng như thủ công nghiệp đáp ứng dịch vụ mua sắm của du khách; tăng cường hệ thống điện, thông tin liên lạc,... tại các điểm du lịch.

Bốn là, đào tạo nguồn nhân lực có chất luợng để phát triển du lịch sinh thái. Huyện cần cử các cán bộ theo học các khóa học đào tạo về tổ chức và quản lí các họat động du lịch sinh thái, nghiệp vụ kinh doanh du lịch, công tác giáo dục môi trường...; Khuyến khích tạo điều kiện để các cán bộ trẻ được đào tạo một cách bài bản về hoạt động du lịch sinh thái; đào tạo về kĩ năng giao tiếp, ngoại ngữ và văn hóa cộng đồng địa phương. Những kiến thức cơ bản về lâm nghiệp, về thiên nhiên môi trường; thường xuyên tiến hành kiểm tra đánh giá, phân loại trình độ nghiệp vụ của các cán bộ nhân viên làm trong ngành du lịch của địa phương. Ngoài ra, cần có các chương trình đào tạo các hướng dẫn viên du lịch sinh thái; cần chú ý tới việc đào tạo người dân địa phương có năng lực để họ trở thành những hướng dẫn viên du lịch phục vụ cho hoạt động du lịch sinh thái ngay trên địa phương của mình.

Đồng thời, huyện cần đẩy mạnh công tác tuyên truyền nâng cao nhận thức của các cấp, các ngành, của cán bộ đảng viên và nhân dân địa phương về phát triển kinh doanh du lịch; tổ chức tham quan, học tập kinh nghiệm về công tác tổ chức - quản lí các hoạt động du lịch tại các vườn quốc gia, khu bảo tồn có hoạt động du lịch.

Năm là, đẩy mạnh công tác quảng bá, xúc tiến du lịch. Phòng Văn hóa, Thể thao và Du lịch huyện Lục Ngạn cần xây dựng chương trình, kế hoạch về xúc tiến quảng bá du lịch phù hợp với chiến lược chung của tỉnh Bắc Giang nhưng mang dấu ấn về phát triển du lịch sinh thái giàu bản sắc văn hóa địa phương. Đẩy mạnh xã hội hóa trong công tác quảng bá, xúc tiến du lịch. Làm phim truyền hình về du lịch, xây dựng các chuyên đề, chuyên mục, tin bài tuyên truyền về phát triển du lịch phát sóng định kỳ hàng tuần, tháng, năm trên Đài phát thanh và truyền hình huyện Lục Ngạn, báo Bắc Giang, VOV, Tạp chí Du lịch,... để quảng bá về miền đất, con người huyện Lục Ngạn, cơ chế chính sách khuyến khích ưu đãi đầu tư phát triển du lịch huyện. Tổ chức hội thảo về du lịch, các cuộc thi ảnh hay thiết kế các bộ định dạng về thương hiệu để tạo nên sự thống nhất và các nét đặc trưng nhằm định vị thương hiệu 
cho du lịch huyện Lục Ngạn trong lòng khách du lịch. Các trang website của Lục Ngạn và doanh nghiệp du lịch cần phải được cập nhật về điểm đến thường xuyên, đảm bảo sự phong phú đa dạng về nội dung, hình thức đầy đủ, chính xác, hình ảnh chân thực, rõ nét gây ấn tượng. Cần bổ sung hệ thống biển báo chỉ dẫn bao gồm cả biển chỉ dẫn an toàn cho du khách đặc biệt là khu vực lòng hồ, khu vực thác,...; biển chỉ dẫn về an toàn giao thông hoặc những chỉ dẫn về điểm đến. Cần có những câu trích dẫn về truyền thuyết, tích xưa hoặc cội nguồn của những bài thơ, câu hát của đồng bào dân tộc tại những nơi có phong cảnh đẹp mà phù hợp với trích dẫn. Hiện nay, những thay đổi về công nghệ thông tin truyền thông đã cung cấp cho người dân những dữ liệu về sản phẩm du lịch phong phú và đầy đủ hơn. Mặt khác, du khách hiện nay đã và đang tìm kiếm thông tin điểm đến thông qua các kênh Internet như Facebook, Blog và các trang mạng xã hội khác. Vì vậy, huyện cần tổ chức các lớp đào tạo, tập huấn bồi dưỡng kĩ năng truyền thông du lịch cho cán bộ làm công tác truyền thông. Đồng thời, mỗi người dân cũng cần là một đại sứ du lịch thì công tác quảng bá hình ảnh quê hương Lục Ngạn đến du khách thập phương một cách chân thực và hữu ích.

Sáu là, thu hút sụ tham gia của cộng đồng địa phwơng trong hoạt động du lịch. Hoạt động khai thác du lịch sinh thái ở huyện Lục Ngạn đã thực hiện nhưng ảnh hương, hiệu quả của hoạt động này đối với đời sống của cư dân địa phương chưa cao. Để thu hút cộng đồng địa phương tham gia vào các hoạt động khai thác du lịch sinh thái, chính quyền các cấp ở huyện Lục Ngạn cần chỉ đạo các phòng chuyên môn hướng dẫn các tổ chức, cá nhân, doanh nghiệp, hộ gia đình phối hợp chặt chẽ, nâng cao năng lực chuyên môn, kĩ năng nghiệp vụ, chất lượng dịch vụ trong việc khai thác và triển khai các kế hoạch phát triển du lịch địa phương.

Bảy là, liên kết hợp tác phát triển du lịch sinh thái trong vùng. Huyện Lục Ngạn ở vị trí phía Đông Bắc tỉnh Bắc Giang, gần các trung tâm du lịch đã phát triển như Hà Nội, Bắc Ninh, Lạng Sơn, Quảng Ninh. Đây là điều kiện thuận lợi để huyện phát triển kết nối các tour, các tuyến du lịch khác trong tỉnh và các vùng xung quanh. Căn cứ vào tiềm năng du lịch của huyện Lục Ngạn nói riêng và cả tỉnh Bắc Giang nói chung, huyện cần có những định hướng, chính sách thu hút các nhà đầu tư quan tâm đầu tư xây dựng cơ sở vật chất kĩ thuật cho các loại hình kinh doanh dịch vụ du lịch như các nhà hàng, khách sạn, khu vui chơi giải trí,.. để có thể xây dựng một số tuyến du lịch như: các tuyến du lịch trong tỉnh (Bắc Giang - chùa Vĩnh Nghiêm - suối Mỡ - vườn cây ăn quả Lục Ngạn; Bắc Giang - suối Mỡ - vườn cây ăn quả Lục Ngạn - hồ Khuôn
Thần - đền nếu đín cụ. Từ Hả - chùa Am Vãi...), các tuyến du lịch ngoại tỉnh như (Các tỉnh - Bắc Giang - Suối Mỡ Vườn cây ăn quả Lục Ngạn - Rừng; Khe Rỗ - rừng Tây Yên Tử; Các tỉnh - Bắc Giang - Suối Mỡ - Hồ Cấm Sơn Hang Gió (Lạng Sơn); các tỉnh Bắc Giang - Suối Mỡ - Hồ Khuôn Thần - Côn Sơn (Hải Dương).

\section{Kết luận}

Huyện Lục Ngạn, tỉnh Bắc Giang là một huyện miền núi sở hữu một tiềm năng du lịch hết sức phong phú, đặc biệt là về du lịch sinh thái, bao gồm tiềm năng về tự nhiên và tiềm năng về nhân văn độc đáo như: Hồ Khuôn Thần, hồ Cấm Sơn, chùa Am Vãi, các vườn đồi cây ăn quả, làn điệu dân ca của các tộc người thiểu số, phiên chợ vùng cao, làng nghề truyền thống,... Những tiềm năng đó là điều kiện thuận lợi lớn cho việc phát triển du lịch sinh thái tại địa phương, song vẫn còn những khó khăn không nhỏ trong việc khai thác và quy hoạch các tiềm năng đó thành các điểm du lịch sinh thái hấp dẫn. Để khai thác hiệu quả tiềm năng và phát triển du lịch sinh thái ở huyện Lục Ngạn, các cấp chính quyền địa phương cần phải có những định hướng lâu dài trong việc quy hoạch, phát triển các loại hình du lịch tương xứng với tiềm năng của huyện và từ đó đưa ra những biện pháp kịp thời, phù hợp và hiệu quả. Lục Ngạn hứa hẹn là một điểm du lịch, du lịch sinh thái hấp dẫn du khách trong thời gian tới..

\section{TÀI LIỆU THAM KHẢO}

[1]. Nhiều tác giả (2018), Luật Du lịch (Hiện hành), Nhà xuất bản Chính Trị Quốc Gia Sự Thật.

[2]. Thư viện Học liệu Mở Việt Nam (VOER), https://voer.edu.vn/.

[3]. UBND huyện Lục Ngạn (2018), Báo cáo tình hình Kinh tế - Xã hội năm 2018.

[4]. https://lucngan.bacgiang.gov.vn

[5]. Nguyễn Đình Hoè, Vũ Văn Hiếu (2001), Du lịch bền vũng, Nxb Đại học Quốc gia Hà Nội.

[6]. IUCN, VNAT, ESCAP (1999), Tuyển tập báo cáo hội thảo "Xây dụng chiến lược quốc gia về phát triển Du lịch sinh thái tại Việt Nam, Hà Nội. 


\section{Exploiting the potential for eco-tourism development in Luc Ngan district, Bac Giang province}

Nguyen Thi Hoa,

Vi Thi Nhung

\begin{tabular}{l}
\hline Article info \\
\hline Recieved: \\
29/4/2020 \\
Accepted: \\
10/6/2020 \\
\hline
\end{tabular}

\begin{tabular}{l} 
Abstract \\
\hline In Vietnam, tourism is identified as one of the country's key economic sectors. \\
Tourism not only brings economic benefits, plays a role of promoting and preserving \\
traditional cultural values, but also has the significance of protecting the natural and \\
social environment with the form of eco-tourism. Each locality in our country has the \\
potential to develop tourism in general and eco-tourism in particular. The article aims \\
to study the exploitation of eco-tourism potential in Luc Ngan district, Bac Giang \\
province. We use historical and logical methods, interdisciplinary research methods \\
(synthesis, statistics, analysis, comparison ...), especially the ethnographic fieldwork \\
method to conduct the gathering data and conducting research. The article clarifies \\
and assesses the potential of ecotourism, researches the actual situation of exploiting \\
the potential of local tourism development; on that basis, The article considers and \\
proposes orientations and solutions to effectively exploit the potential of eco-tourism \\
development in Luc Ngan district, Bac Giang province. The research results contribute \\
to confirming the ecotourism potential of Luc Ngan district and it is the basis for the \\
locality to build a comprehensive project, orienting and implementing solutions to \\
develop eco-tourism and tourism
\end{tabular}

Keywords:

Magic, tourism, guides, belief, mysterious 